\title{
Concentration of Progesterone and Prolactin Hormones and Milk Production of New Zealand White Rabbits Doe Fed Moringa Leaves Meal
}

Markus Miten Kleden ${ }^{1,3}$

Hendrawan Soetanto ${ }^{1}$

Kusmartono ${ }^{1}$

\author{
Kuswanto ${ }^{2}$ \\ ${ }^{1}$ Faculty of Animal Husbandry, Brawijaya University - Malang, Indonesia \\ 2Faculty of Agriculture, Brawijaya University - Malang, Indonesia \\ ${ }^{3}$ Current address: Faculty of Animal Husbandry, \\ University of Nusa Cendana - Kupang, East Nusa Tenggara, Indonesia
}

Doi:10.5901/mjss.2017.v8n3p79

\begin{abstract}
The research objectives were to measure the concentration of progesterone and prolactin hormone and milk production of New Zealand White rabbit's doe fed with moringa leaves meal. Blood sample was taken and centrifuged to separate serum and plasma. Then, the blood serum was analyzed applying ELISA method using ELISA kit EIA 1561 for progesterone hormone and rabbit prolactin ELISA kit cat no. E-EL-RB1223 for prolactin hormone. The milk production was measured daily by weighting the body weight of rabbit kids before and after milking. Data analysis using anova method applying program SPSS version 20 for windows. Moringa leaves meal fed tends to increase the concentration of progestrone hormone during pregnancy period and it decline sharply in post natal. The higher the level of moringa leaves meal, the higher the production of prolactin hormone at natal period. This fact doe to amino acids content of moringa leaf meal particularly essential amino acids. The main function of amino acid was in hormone and transmitter synthesis. Decrease of prolactin inhibitor and increase of prolactin secretion at natal period as an effect of amino acids content in moringa leaves meal. Increasing of prolactin level will followed by milk excretion. Increase of milk production caused by galactogogue effect of moringa leaves meal. The increasing of moringa leaves meal level influences milk production in milking period and produces a higher body weight at post weaning period comparing with without the moringa leaves meal. Using moringa leaves meal is suggested in order it increase livestock milk production in dry land areas to overcome kid's mortality problem.
\end{abstract}

Keywords: Moringa leaves meal, New Zealand white rabbit, progesterone, prolactin, milk excretion

\section{Introduction}

Moringa is the main vegetable in dry-land areas doe to its availabilty and low price. This plant is widely adaptive mostly in marginal land. The using of moringa leaves to overcome calf mortality at pre weaning priod in dry-land areas. The mortality of calf is influenced by the low production of milk doe to the insufficient nutrition consumed mainly protein and amino acid.

Moringa contains protein and essential amino acids. As the material contents with equal protein and essential amino acids, moringa leaves have high contribution toward the increasing of growth and organism level of health mainly to increase rural community health, supplement for pregnant women and to recover type 2 diabetes. Moringa also called as a life tree plant either as protein and amino acids that include other bioactive and useful to overcome malnutrition. Therefore, many types of research were conducted particularly its relationship with the growth and body metabolic change.

There are various amino acids in moringa depend on plant species, yield age, and other environmental factors. Since it contains several of protein and amino acids, moringa leaves are sometimes used mostly to tackle problems encountered primarily related to the adequacy of protein. 
Each amino acid plays a different role in the body, yet interaction between amino acids supports the growth and synthesis of amino acids, include body protein besides as source of hormone synthesis and transmitter. Many studies have extensively evaluated moringa protein that influences animal growth such as birds, rabbits, as well as other ruminants. The effectiveness of protein and amino acids in moringa as a source of galactagogue has been studied. Despite one of the roles of amino acids is a synthesis of hormone in the body, but there is lack of information related to the function of moringa leaves in influencing synthesis of progesterone and prolactin hormones of the body and also related to milk production, therefore this study was conducted to provide comprehensive information.

\section{Materials and Method}

\subsection{Experimental Animals}

Twenty-five New Zealand White (NZW) rabbit does about 1 year-old with average body weight $2.392 \pm 0.39 \mathrm{~kg}$ was put in an individual cage. Besides, 5 male NZW rabbits were also prepared. The breeding was done naturally. The formulate feed of the rabbits consist of carrots, water spinach and concentrate contained different level of moringa leaves' meal. The fresh moringa leaves from East Flores Regency was sun dried and ground then mixed with other feed component as concentrate. Concentrate fed as pellet shape. Chemical composition and concentrate proportion were based on the standard of protein and crude fiber that needed by the rabbit as shown in Table 1.

Table 1. Proportion of supplement-formulated feed

\begin{tabular}{|l|c|c|c|c|c|c|c|}
\hline \multirow{2}{*}{ Type of feed } & \multicolumn{2}{|c|}{ Nutrient content } & \multicolumn{5}{|c|}{ Proportion (\%)/ Treatments } \\
\cline { 2 - 8 } & $\mathrm{CP}$ & $\mathrm{CF}$ & $\mathrm{K} 0$ & $\mathrm{~K} 6$ & $\mathrm{~K} 12$ & $\mathrm{~K} 18$ & $\mathrm{~K} 24$ \\
\hline Fish meal & 70.11 & 0.53 & 3 & 3 & 3 & 3 & 3 \\
\hline Coconut meal & 23.92 & 16.65 & 1 & 3 & 5 & 7 & 9 \\
\hline Corypha gebanga flour & 3.16 & 10.82 & 15 & 13 & 10 & 6 & 2 \\
\hline Moringa leaves' meal & 32.7 & 7.55 & 0 & 6 & 12 & 18 & 24 \\
\hline Soybean flour & 40.69 & 10.74 & 24 & 18 & 12 & 6 & 0 \\
\hline Mill corn & 10.36 & 1.19 & 32 & 31 & 31 & 32 & 33 \\
\hline Rice bran & 9.57 & 24.27 & 23 & 24 & 25 & 26 & 27 \\
\hline Salt & & & 1 & 1 & 1 & 1 & 1 \\
\hline Premix & & & 1 & 1 & 1 & 1 & 1 \\
\hline Total & & & 100 & 100 & 100 & 100 & 100 \\
\hline Total CP & & & 18.09 & 18.03 & 18.03 & 18.09 & 18.17 \\
\hline Total CF & & 10.35 & 10.5 & 10.56 & 10.53 & 10.49 \\
\hline
\end{tabular}

Note: $\mathrm{CP}=$ Crude Protein; $\mathrm{CF}=$ Crude Fiber

The waste of water spinach was fed ad libitum, while carrot and the concentrate were fed $50 \mathrm{~g} / \mathrm{head} /$ day.

\subsection{Blood Sample Analysis}

Blood samples were taken at $5 \mathrm{pm}$, in three times in order to evaluate progesterone and prolactin levels. First, before the rabbits bred. Second was during pregnancy. Third was one day after post-partum. The blood samples were taken from vena behind the rabbits' ear in the amount of $\pm 3 \mathrm{cc}$, and then centrifuged at $3000 \mathrm{rpm}$ of speed in order to separate serum and plasma. The blood serum, were put into eppendorf tube and kept at $-20^{\circ} \mathrm{C}$ temperature. Further, the blood serum samples were analyzed by applying ELISA method using rabbit prolactin ELISA kit with a catalog number E-ELRB1223 prolactin. While progesterone ELISA kit EIA-1561 was used for progesterone hormone. Birth weight of litter was weighed for each rabbit doe just in time of postpartum. Milk production was measured by weighing before and after milking of litter for each doe during the lactation period. Mortality rate was counted based on the number of litter death during the lactation period. Analysis procedure of the progesterone and prolactin was as follows:

\subsubsection{Progesterone Hormone}

The measurement of the rabbits' progesterone level in blood serum samples were done by applying ELISA method using progesterone ELISA kit EIA 1561. Standard and antigen were $25 \mu \mathrm{L}$ of the rabbits' blood serum put into antibody coated 
well. The tube, then, was incubated at $37^{\circ} \mathrm{C}$ for $60 \mathrm{~min}$. The residual unreacted antigen was removed and added with 200 $\mu \mathrm{L}$ Biotin-antibody in each well. Further, incubated the well for 15 minutes at $37^{\circ} \mathrm{C}$. Aspirated fluid in the well and rinsed using wash buffer three times. Moreover, added with $400 \mu \mathrm{L} \mathrm{HRP} \mathrm{conjugate} \mathrm{in} \mathrm{each} \mathrm{well} \mathrm{and} \mathrm{incubated} \mathrm{for} 30$ minutes at the temperature of $37^{\circ} \mathrm{C}$. The aspiration process was repeated and rinses the well using wash buffer 5 times. Then, added with $200 \mu \mathrm{L}$ substrate TMB in each well and incubated it for 15 minutes at $37^{\circ} \mathrm{C}$ of temperature (avoid it from the light). For stop reaction, added with $100 \mu \mathrm{L}$ stop solution into each well. After 10 min read it using ELISA Reader at a frequency of $450 \mathrm{~nm} \pm 10$.

\subsubsection{Prolactin Hormone}

The measurement of rabbit prolactin level in blood serum was done by applying Sandwich ELISA using PRL (Prolactin) ELISA kit (Cat. No. E-EL-RB1223). Sandwich ELISA started by Coating antigen Prolactin. Standard and antigens in the form of $100 \mu \mathrm{L}$ rabbits' blood serum were put into antibody coated well. Then, incubated the well at $37^{\circ} \mathrm{C}$ of temperature in 90 minutes. The residual antigen that does not react were removed and added with $100 \mu \mathrm{L}$ Biotin-antibody for each well. Further, the wells were incubated for one hour at $7^{\circ} \mathrm{C}$ of temperature. The liquid in the wells was aspirated and rinsed the well using wash buffer three times. An amount of $100 \mu \mathrm{L}$ HRP conjugate were added to each well and incubated for $30 \mathrm{~min}$ at $37^{\circ} \mathrm{C}$. The aspiration process was repeated and rinsed using wash buffer 5 times. Then, added with $90 \mu \mathrm{L}$ substrate $\mathrm{TMB}$ in each well then incubated for $15 \mathrm{~min}$ at $37^{\circ} \mathrm{C}$ (avoid the wells from light). For stop reaction, added $50 \mu \mathrm{L}$ stop solution at each well. After 5 min, read it using ELISA Reader at the frequency of $450 \mathrm{~nm}$.

\subsection{Statistical Analysis}

Completely Randomized Design was used as experimental design consists of 5 treatments and 5 replications. The treatments were $\mathrm{K} 0, \mathrm{~K} 6, \mathrm{~K} 12, \mathrm{~K} 18, \mathrm{~K} 24=$ moringa leaves the amount of $0,6,12,18,24 \%$ respectively. The data collected then analyzed by analysis of variance and followed by least significant difference test with used SPSS software verse 18 for windows.

\section{Result and Discussion}

The result of nutrient content analysis of base ration as presented in Table 2 and concentrate as presented in Table 3.

Table 2. Proximate analysis of base ration

\begin{tabular}{|c|c|c|c|c|c|c|}
\hline \multirow{3}{*}{ Feed materials } & \multicolumn{6}{|c|}{ Items } \\
\hline & $\mathrm{DM}(\%)$ & $\mathrm{CP}$ & CL & $\mathrm{CF}$ & NFE & Ash \\
\hline & & \multicolumn{5}{|c|}{ 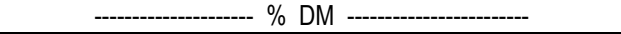 } \\
\hline Water spinach & 9.26 & 24.24 & 3.07 & 18.29 & 40.25 & 14.15 \\
\hline Carrots & 15.09 & 18.82 & 5.85 & 10.08 & 57.13 & 8.12 \\
\hline
\end{tabular}

Note: $\mathrm{DM}=$ dry matter; $\mathrm{CL}=$ crude lipida; NFE = nitrogen free extract

Table 3. Proximate analysis of concentrate formulation

\begin{tabular}{|c|c|c|c|c|c|c|}
\hline \multirow{3}{*}{ Feed materials } & \multicolumn{6}{|c|}{ Items } \\
\hline & $\mathrm{DM}(\%)$ & $\mathrm{CP}$ & $\mathrm{CL}$ & $\mathrm{CF}$ & NFE & Ash \\
\hline & & \multicolumn{5}{|c|}{ - } \\
\hline Fish meal & 89.28 & 70.11 & 4.84 & 0.44 & 5.06 & 19.46 \\
\hline Coconut meal & 87.54 & 23.92 & 11.90 & 16.65 & 40.47 & 7.06 \\
\hline Corypha gebanga flour & 90.22 & 3.16 & 0.67 & 10.82 & 81.94 & 3.41 \\
\hline Moringa leaves' meal & 88,91 & 32.7 & 7.73 & 7.55 & 41.64 & 10.38 \\
\hline Soy bean flour & 89.26 & 40.69 & 15.30 & 10.74 & 28.02 & 5.25 \\
\hline Mill corn & 89.27 & 10.36 & 1.79 & 1.18 & 83.54 & 3.13 \\
\hline Rice bran & 88.94 & 9.57 & 10.45 & 24.26 & 38.47 & 17.25 \\
\hline
\end{tabular}

The experiment used the same quality of concentrate for each treatment as shown in Table 4 primarily the minimal amount of protein content and crude fiber for rabbit. 
Table 4. Proximate analysis of concentrate

\begin{tabular}{|c|c|c|c|c|c|c|c|}
\hline \multirow{3}{*}{ Treatment } & \multicolumn{6}{|c|}{ Items } & \multirow{3}{*}{ GE (Kcal/kg DM) } \\
\hline & DM (\%) & CP & $\mathrm{CL}$ & CF & NFE & Ash & \\
\hline & & \multicolumn{5}{|c|}{ - } & \\
\hline KO & 89.36 & 18.07 & 6.51 & 10.15 & 57.68 & 7.59 & 4280.94 \\
\hline K6 & 90.59 & 17.93 & 5.21 & 10.50 & 58.25 & 8.11 & 4160.59 \\
\hline K12 & 89.31 & 17.98 & 5.86 & 10.52 & 56.82 & 8.82 & 4265.90 \\
\hline K18 & 87.93 & 18.01 & 5.61 & 10.69 & 56.49 & 9.20 & 4125.30 \\
\hline K24 & 88.80 & 17.97 & 5.82 & 10.87 & 56.15 & 9.19 & 4103.20 \\
\hline
\end{tabular}

The values of the feed nutrient consumption are shown in Table 5.

Table 5. Consumption and nutrient digestion

\begin{tabular}{|l|c|c|c|c|c|}
\hline \multirow{2}{*}{ Parameters } & \multicolumn{5}{|c|}{ Treatments } \\
\cline { 2 - 6 } & K0 & K6 & K12 & K18 & K24 \\
\hline Consumption: & & & & & \\
\hline Dry Matter (g/kgbw0.75/day) & $38.62 \pm 3.7$ & $39.94 \pm 5.1$ & $39.55 \pm 3.8$ & $39.75 \pm 6.6$ & $39.21 \pm 4.1$ \\
\hline Crude Protein (g/kgbw0.75/day) & $7.75 \pm 0.7$ & $8.08 \pm 1.0$ & $7.97 \pm 0.8$ & $8.01 \pm 1.3$ & $7.93 \pm 0.8$ \\
\hline Crude Fiber (g/kgbw0.75/day) & $4.90 \pm 0.5$ & $5.27 \pm 0.7$ & $5.16 \pm 0.5$ & $5.22 \pm 0.9$ & $5.24 \pm 0.5$ \\
\hline Organic Matter (g/kgbw0.75/day) & $34.88 \pm 3.3$ & $35.86 \pm 4.5$ & $35.39 \pm 3.4$ & $32.47 \pm 2.4$ & $34.97 \pm 3.6$ \\
\hline
\end{tabular}

The average of dry matter and other nutrients consumption were relatively similar for each treatment. It shows that moringa leaves' meal has no influence towards the increasing of ration dry matter consumption. The research found that the consumption ratio value is lower than of the result of who reported that the value was $95.2 \mathrm{~g} / \mathrm{kgbw}^{0.75}$. The difference may occur as a cause of different feed used and other environmental factors particularly the high temperature that limits the amount of ration consumption.

The same values of ration consumption for each treatment have the same influence toward birth weight, littersize, and weaning weight as presented in Table 6 . However, the increasing of moringa leaves' meal levels tends to produce a higher birth weight as well as weaning weight.

Table 6. Birth weight, litter size, and weaning weight of the litter

\begin{tabular}{|l|c|c|c|c|c|}
\hline \multirow{2}{*}{ Parameter } & \multicolumn{5}{|c|}{ Treatments } \\
\cline { 2 - 6 } & K0 & K6 & K12 & K18 & K24 \\
\hline Birth weight $(\mathrm{g})$ & $45.98 \pm 6.8$ & $46.14 \pm 6.2$ & $50.73 \pm 7.9$ & $49.90 \pm 4.6$ & $53.19 \pm 4.5$ \\
\hline Weaning weight $(\mathrm{g})$ & $270.33 \pm 128.7$ & $309.45 \pm 85.4$ & $321.37 \pm 103.5$ & $334.60 \pm 86.2$ & $332.93 \pm 100.7$ \\
\hline Litter size & $6.8 \pm 1.6$ & $6.8 \pm 2.1$ & $4.8 \pm 1.9$ & $5.2 \pm 1.6$ & $5.8 \pm 1.3$ \\
\hline
\end{tabular}

The average birth weight is $49.19 \pm 3.1 \mathrm{~g}$ and it is higher than that as reported by with birth weight $42.07 \pm 0.76 \mathrm{~g}$. However, the weaning weight gained to have a different result. Our weaning weight was $313.74 \pm 26.29 \mathrm{~g}$, while reported that the weaning weight was $533.29 \pm 7.24 \mathrm{~g}$. Several factors such as nutrition, age, and disease influent the litter size and climate implicate to the birth weight. Although there are similar values of feed intake between treatments, different levels of moringa leaves' meal used tend to produce the different concentration of progesterone and prolactin hormones.

Despite its potential relationship between moringa leaves meal and concentration of progesterone and prolactin, there has no significant effect $(P>0.05)$ on progesterone concentration and high significant effect $(P<0.05)$ on prolactin concentration particularly during lactation period. A high concentration of progesterone hormone supports the process of fetus implantation onto uterus wall avoid premature beside other biologic function. The concentration of progesterone hormone increases since 2-3 day of pregnancy and reach its peak at the fourth of pregnancy period. The result shows that the higher level of moringa leaves' meal has a significant influence $(P<0.05)$ in increasing of prolactin hormone concentration as shown in Table 7. 
Table 7. Concentration of progesterone and prolactin hormones

\begin{tabular}{|c|c|c|c|c|c|}
\hline \multirow{2}{*}{ Parameter } & \multicolumn{5}{|c|}{ Treatment } \\
\hline & KO & K6 & K12 & K18 & K24 \\
\hline $\begin{array}{l}\text { Before mating: } \\
\text { Progesterone (ng/ml) } \\
\text { Prolactine (ng/ml) }\end{array}$ & $\begin{array}{c}0.3 \pm 0.0 \\
0.37 \pm 0.0\end{array}$ & $\begin{array}{l}0.85 \pm 0.5 \\
0.38 \pm 0.0\end{array}$ & $\begin{array}{l}0.63 \pm 0.9 \\
0.38 \pm 0.0\end{array}$ & $\begin{array}{l}0.67 \pm 0.6 \\
0.38 \pm 0.0\end{array}$ & $\begin{array}{l}0.78 \pm 0.5 \\
0.37 \pm 0.0\end{array}$ \\
\hline $\begin{array}{l}\text { During Pregnant: } \\
\text { Progesterone (ng/ml) } \\
\text { Prolactine (ng/ml) }\end{array}$ & $\begin{array}{c}3.1 \pm 2.8 \\
1.97 \pm 0.5\end{array}$ & $\begin{array}{l}5.85 \pm 4.9 \\
1.97 \pm 0.3\end{array}$ & $\begin{array}{l}5.63 \pm 1.9 \\
2.22 \pm 0.4\end{array}$ & $\begin{array}{c}14.87 \pm 11.7 \\
2.00 \pm 0.2\end{array}$ & $\begin{array}{c}24.43 \pm 20.1 \\
2.31 \pm 0.2\end{array}$ \\
\hline $\begin{array}{l}\text { During Lactation: } \\
\text { Progesterone }(\mathrm{ng} / \mathrm{ml}) \\
\text { Prolactine }(\mathrm{ng} / \mathrm{ml})\end{array}$ & $\begin{array}{c}0.2 \pm 0.2 \\
0.84 \pm 0.1 \mathrm{a}\end{array}$ & $\begin{array}{c}0.87 \pm 0.8 \\
0.88 \pm 0.1^{\mathrm{a}}\end{array}$ & $\begin{array}{l}0.52 \pm 0.7 \\
1.03 \pm 0.1^{\mathrm{b}}\end{array}$ & $\begin{array}{c}0.52 \pm 0.7 \\
0.93 \pm 0.1 \mathrm{ab}\end{array}$ & $\begin{array}{l}0.52 \pm 0.7 \\
1.03 \pm 0.1 b\end{array}$ \\
\hline
\end{tabular}

Different superscript on same line shows the difference occurs $(P<0,05)$

The elevated of prolactin level occurs due to amino acid compound in moringa leaves' meal plays a role in limiting the concentration of prolactin inhibitor factor. Amino acids that contained in the moringa, such as phenylalanine, will be transformed into tyrosine amino acid that function to formulate protein, neurotransmitter include epinephrine, L-dopa, and norepinephrine. The increasing of prolactin hormone influence the increasing of milk production of doe during lactation period as presented in Table 8, while milk production of each treatment from the week I until week IV are demonstrated in Fig 1.

Table 8. Milk production and litters mortality

\begin{tabular}{|l|c|c|c|c|c|}
\hline \multirow{2}{*}{ Parameter } & \multicolumn{5}{|c|}{ Treatment } \\
\cline { 2 - 6 } & K0 & K6 & K12 & K18 & K24 \\
\hline Milk production in lactation periods (g/30 days) & $1349 \pm 96.7^{\mathrm{b}}$ & $1397.6 \pm 85.9^{\mathrm{b}}$ & $1409 \pm 99.7^{\mathrm{b}}$ & $1425.4 \pm 120.1^{\mathrm{ba}}$ & $1555.8 \pm 71.4^{\mathrm{a}}$ \\
\hline Birth rate (head) & $34 \pm 1.6$ & $34 \pm 2.1$ & $24 \pm 1.9$ & $26 \pm 1.6$ & $29 \pm 1.3$ \\
\hline Mortality (\%) & $41.0 \pm 19.6$ & $36.4 \pm 27.4$ & $19.7 \pm 21.1$ & $19.5 \pm 21.8$ & $15.24 \pm 15.6$ \\
\hline
\end{tabular}

Different superscript on the same line shows there was a difference occurs $(P<0.05)$.

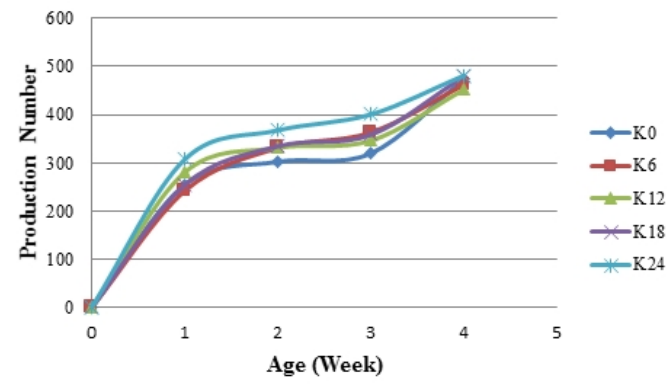

Figure 1. Milk production during lactation period (g/week)

The increased level of using moringa leaves meal was followed by the increasing of milk production doe to galactogogue effect of moringa leaves meal. The research found that the average of milk production of each level of moringa leaves meal during lactation period was $1349 \pm 96.7 \mathrm{~g} ; 1397.6 \pm 85.9 \mathrm{~g} ; 1409 \pm 99.7 \mathrm{~g} ; 1425.4 \pm 120.1 \mathrm{~g}$ and $1555.8 \pm 71.4 \mathrm{~g} / 30$ day, respectively. It is lower than reported by other studies such as who reported that rabbit's milk production was $145 \pm 64$ $\mathrm{g} /$ day and $7636 \mathrm{~g} / 30$ day. The difference of environment condition, rabbit genetic as well as feed quality and type used are several possible factors cause the differences. Even though milk production tends to increase due to the increasing of moringa leaves' meal, however the mortality rate was relatively higher than the previous study as reported by who reported that the mortality of rabbit litter was $14.4 \%$ while reported that mortality of NZW rabbit litter at age of $0-21$ days was $14.27 \pm 3,32 \%$ in autumn and $14,98 \pm 3,19 \%$ in summer. Our finding suggests that rabbit litter' mortality commonly occurs at age of $1-2$ week as shown in Fig 2. 


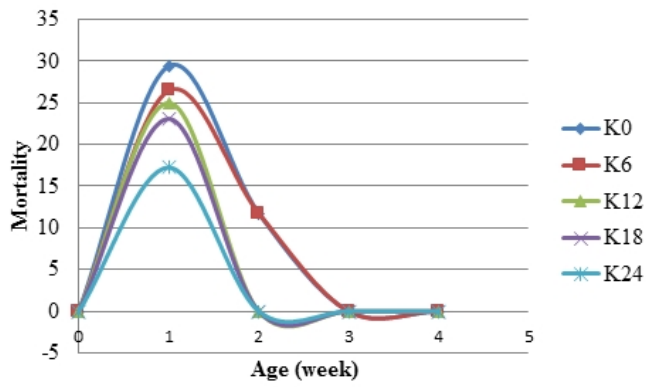

Figure 2. Percentage mortality during the lactation period

The litter competition ability to reach mamae nipple during milking influence the ability to live. The less competitive rabbit litter will die because insufficient nutrient.

\section{Conclusion}

Our finding demonstrates the using of moringa leaves' meal in ration increase of progesterone and prolactin hormones concentration, milk production and as well as declined of mortality rate.

\section{Acknowledgements}

This article is a part of doctoral research of the first author in field of Animal Science, Faculty of Animal Husbandry, and University of Brawijaya, Indonesia. The other says a lot of thank you for financial support funded by Directorate General of Higher Education, Department of Research, Technology and Higher Education Republic of Indonesia. Special thanks' also for Mr. Theodorus Niron who support us in preparing leaves, Mr. Suadi Akhiriyanto for his help in preparing rabbit cages and take care the rabbits, and Mr. Sugiyono for his support in providing all tools and maintenance of Animal Nutrition Laboratory for proximate analysis. At last, thanks' a lot for Ms. Nini at Biochemistry Laboratory, Faculty of Math and Science, University of Brawijaya for all support in hormone analysis.

\section{References}

Nouman, W., S.M.A. Basra, M.T. Siddiqui, A. Yasmeen, T. Gull, M.A.C. Alcayde (2014). Potential of Moringa oleifera L. as livestock fodder crop: A review. Turk. J. Agric. For. 38: 1-14.

Agbogidi, O.M., and E.M. Illondu (2012). Moringa oleifera lam: its potential as a food security and rural medicinal item. J. Bio. Innov. 1(6): 156-167.

Surbhi, K., P. Prasad, A. Roy, and R.K. Sahu (2014). An overview on phytochemistry and pharmacological explorations of Moringa oleifera. UK Journal of Pharmaceutical and Biosciences. 2(1): 34-41.

Kumar, P.K., and R.J. Mandapaka (2013). Effect of Moringa oleifera on blood glucose, LDL levels in type II diabetic obese people. Inovative Journal of Medical and Health Science. 3(1): 23-25.

Sixl, D., Karin, W. Sixl, G. Sixl, and W. Fuchs 2014. On the use of Moringa oleifera as a medicinal plant in India and Philippines. Egészségtudomány, Lv. Évfolyam. 55(3): 57-63.

Azeez, F.A., M.O. Nosiru, N.A. Clement, D.A. Awodele, D. Ojo, and O. Arobomen (2013). Importance of Moringa oleifera tree to human livehood: a case study of Isokan local government area in Osun state. Elixir Agriculture. 55(2013): 12959-12963.

Anwar, F., S. Latif, M. Ashraf, and A.H. Gilani (2014). Moringa oleifera: a food plant with multiple medicinal uses. Phytoter. Res. 21: 1725.

Otitoju, O, J.U. Nwamarah, G.T.O. Otitoju, A.U. Okorie, C. Stevens, and K.P. Baiyeri (2014). Effect of Moringa Oleifera aqueous leaf extract on some haematological indices in Wistar rats. Journal of Natural Sciences Research. 4(4): 74-77.

Fugli, L. (2008). New uses of Moringa studied in Nicaragua. ECHOs Technical Network Site. 1-7.

Soetanto, H., and F. Firsoni (2008). Effect of supplementation with molasses block containing gliricidia or moringa leaves on in vitro gas production and microbial protein synthesis. Abstract Proceedings $10^{\text {th }}$ World Conference on Animal Production, Cape Town, South Africa.

Nuhu, F. (2010). Effect of Moringa leaf meal (MOLM) on nutrient digestibility, growth, carcass and blood indeces of weaner rabbits. M.Sc. Thesis (unpublished). Department of Animal Science Kwame Nkrumah. Faculty of Agriculture and Natural Resources. 
University of Science and Technology.

Soetanto, H., S. Chuzaemi, and E. Marhaeniyanto (2010). Performance of growing goats with and without supplementation of Moringa leaves at Pasrujambe village, regency of Lumajang, East Java. Proceedings of International Seminar on Prospects and Challenges of Animal Production in Developing Countries in the $21^{\text {st }}$ Century.

Rajanandh, M.G., M.N. Satishkumar, K. Elango and B. Suresh (2012). Moringa oleifera Lam. A herbal medicine for hiperlipidemia: A preclinical report. Asian Pacific Journal of Tropical Disease. 2(2): S790-S795.

Adeniji, A.A, and M. Lawal (2012). Effect replacing groundnut cake with Moringa oleifera leaf meal in the diets of grower rabbits. International Journal of Molecular Veterinary Research. 2(3): 8-13.

Estrella, M.C.P., J.B.V. Mantaring, G.Z. David, M.A. Taup (2000). A double-blind, randomized controlled trial on the use of malunggay (Moringa oleifera) for augmentation of the volume ofbreastmilk among non-nursing mothers of preterm infants. The Philipine Journal of Pediatrics. 49(1): 1-5.

Padal, S.B., K. Sathyavathi, P. Chandrasekhar (2013). Ethnomedicinal uses of trees by tribals of Munchangiputtu Mandalam, Visakhapatnam District, Andhra Pradesh, India. International Journal of Pharmacy and Biological. 3(2): 441-449.

Nice, F.J. (2015). Evidence-based practice reports selection and use of galactogogues. ICAN: Infant, Child, \& Adolescent Nutrition. 7(4): $192-194$.

Volek Z., M. Marounek, L. Volková, and E. Kudrnová (2012). Effect of diets containing whole white lupin seeds on milk composition and yield of rabbit does and performance and health of their litters. World Rabbit Science Association Proceedings $10^{\text {th }}$ World Rabbit Congress - September 3 - 6, 2012- Sharm El- Sheikh -Egypt, 585 - 589.

Marai, I.F.M., and A. A. Rashwan (2004). Rabbit behavioural response to climatic and managerial conditions: A review. Arch. Tierz. Dummerstorf. 47(5): 469-482.

Pasupathi, K, M. Sakthivel, H. Gopi, D. Balasubramanyam and M. Babu (2014). Factors influencing pre-weaning growth of rabbits under farm condition. International Journal of Science, Engineering and Technology Research. 3(9): 2301-2303.

Asmakh, M.A. (2007). Reproductive function of progesterone. Middle East Fertility Society Journal. 12(3): 147-152.

Stavy, M., J. Terkel, and F. Kohen (1978). Plasma progesteron level during pregnancy and pseudo-prgenancy in the Hare (Lepus europeaus syriacus). J. Reprod. Fert. 54: 9-14.

Macindoe, J.H. and R.W. Turkington (1973). Stimulation of human prolactine secretion by intravenous infusion of L-tryptophan. The Journal of Clinical Investigation. 52(1973): 1972-19.

Fisher, H. (2011). Research Moringa. https://www.researchmoringa.com/18_Amino_Acids.html [Accessed on February 2016].

Sarich, C. (2014). One tree: Over 92 nutrients and 46 natural antioxidants. http://naturalsociety.com/moringa-oleifera-92-nutrients-46natural antioxidants/\#ixzz3u0tP3CdX [Accessed on February 2016]

Ramos, B.G., J.H. Camacho, R.O. Rodríguez, J. C. Segura-Correa, and C.M. Becerril-Pérez (2010). Heritability of milk yield in a population of rabbits under the conditions of the valley of Mexico. Tropical and Subtropical Agro ecosystems, 12(2010): 681 -683.

Planinc, M., A. Kermauner., Š. Malovrh and M. Kovac (2011). Growth and mortality of SIKA suckling rabbits in Slovenia. Acta argiculturae Slovenica. 98(2): 135-141.

Elmaghraby, M.M.A., and S.Z. Elkholya (2010). Characterizing litter losses in purebred New Zealand white rabbits. Lucrări Știinţfifice Universitatea de Știinţe Agricole și Medicină Veterinară, Seria Zootehnie. 54: 304-310. 